SECTION 12. Geology. Anthropology. Archaeology.

Smith William

researcher of National Museum of Natural History Smithsonian Institution,

Washington, USA

Hasanov Elnur Latif oglu

Ph.D. postgraduate

scholar of Ganja Branch of Azerbaijan National Academy of Sciences,

Ganja, Azerbaijan

\title{
IMPORTANCE OF HANDICRAFT TRADITIONS IN INVESTIGATION OF HISTORY OF URBAN CULTURE IN GANJA
}

Has been investigated the significance of the main typical characteristics of craftsmanship traditions of Ganja on the basis of innovative technologies and methods in research of urban culture in this ancient city. In this scientific work some basic local national traditions also were researched from the historic-ethnological point of view. Ganja

Keywords: urban culture, handicraft branches, innovative methods and technologies,

Ganja is one of the oldest cities and has more than 4000 years old as an urban center. This consideration is proved on the basis of indisputable scientific arguments and facts [1-3]. Development of some local handicraft branches in Ganja historically offered necessary facilities for progress of urban culture:

I. In the territory of Azerbaijan the oldest samples of wood treatment were found in the territory of ancient Ganja. Around Ganja area - in the region of Lake Goy-gol in the IV-III millenniums BC have been discovered wooden thicker board, also wooden sugar bowl, that concern to the end of the II millennium BC, found in Mingechevir pitcher grave are material evidences of science thoughts. Have been discovered, that initial ceramic production in Ganja and its surrounding regions are belong to the VIIIVII millennium BC. In Ganja and its regions during centuries ceramic trade has following kinds: 1. Building ceramic materials. 2. Unglazed ceramic products. 3. Glazed ceramic products [1-3]. During many centuries in this ancient cultural and scientific center developed different branches of craftsmanship.

II. The craftsmanship of carpet-making is one of the important cultural achievements of the Eastern people. In Azerbaijan production of carpets appeared during I millennium BC. In Ganja production of carpets differed with quickly development. Ganja carpets are differing with pile. Thickness indicators of such kind of carpets with comparator small number attract attention ( $25 \times 30)$, composition is more distinct and simple, most of ornamental patterns have geometrical features, in coloring carpet samples were used bright colors, local carpet masters skillfully used buta's amatively patterns [4-6].

III. In traditional production of cloth manufactory trade historically played an important place. This kind of craft that developed on the basis of local raw materials was tied with cotton-growing economy. Since the time of the early Middle Ages, Ganja as Tabriz, Ordubad have been the main center of Azerbaijan in production of cotton cloth. In this ancient city printed cotton and calico fabrics have been widely produced. In traditional cloth productions the main place took the urban mines. In the early 30s of the XIX century in Ganja there were more than 164 people - weaving. The majority of these 
artists were weaving. In Ganja, which was the most important center of cloth production were produced different kinds of cotton cloth. Only in the 30s of the XIX century in Ganja were presently working 30 cloth benches [6; 8].

IV. Traditional textile of art of silk weaving products has a special place in Ganja. In the city formed two main method of silk treatment: 1. Spinning. 2. Winding. Also, historically the traditional art of saddle-making in Ganja developed in direction of cargo and passenger saddle making. Afterwards military, economic and transportation significance of horse was decrease, the demand for goods of saddle-making also was decrease.

Ganja city during centuries considered as one of the main urban cultures and located on the ancient caravan routes, so merchants, travelers, scientists and cultural workers from different countries of the world visited Ganja, and first of all, their visiting helped our nation to integrate their spiritual values to all mankind civilizations. Also in XI century, during the Arab Caliphate flowering, the great thinker Gatran Tabrizi's population in Ganja shows, that Ganja has become a major center of culture and science in the Muslim East. From the sources it becomes clear; in that period in Ganja there were personal and public libraries, medresses as modern universities, observatories and medical centers. Muslim culture has spread to the neighboring Christian states from here. That why, many scientists, poets, architects, artists from different countries of East settled in Ganja. Also, Sheikh Nizami, appreciating Ganja's cultural level more highly, praised his native city "My Babylon". In the middle of the XII century there were schools, medresses, private and public libraries, "The houses of wisdom" and "Health centers" in Ganja. In historical sources there was information that, in Ganja there was a large library "Dar al-kutub" that had been led by a famous scientist Abulfaz al-Nakhchivany. From Sheikh Nizami's reading and the names of the works, it becomes clear, that there were rich libraries in Ganja. The high value of selcugs, that replacing arabs, to the science and culture, was the reason of formation of a new school of poetry, that was founded by Sheikh Nizami in Ganja.

In the scientific and cultural center of the East, in Ganja's literary environment were raised Abu Hafs, Abul Ganji, Abul Ula Ganjavi, Mahsati Ganjavi, Qivami Mutarrizi, Raziya Ganjavi, Mirza Shafi Vazeh, who gave priceless pearls to the treasures of world culture. Especially in that period, presence of such kind of chess-player, composer, thinker women as Mahsati Ganjavi and Raziye, who owned world science and philosophy again shows, that city from cultural point of view, stays on high level [2-7]. In middle ages in spheres of gentle and applied art, Ganja of inhabitants of territory, in agriculture life bone was widely applied. Bone products, raw materials, that found during investigations in and around Ganja prove that time bone processing separated from other spheres of craftsmanship.

Ostheology analysis prove, that most of samples are prepared from the bone of bull, caw, deer among big horde animals and sheep, goat, boar among little horde animals. Only deering investigations in Mingechaur there were found a lot of samples of combs, agriculture instruments and art and other bone things. Such kind of bone samples also were found in monument complexes territory of Injachay and Kerpicli in Goranboy region during excavation. Art samples and dice for playing nard, found in territory Shatal, also attracts our attention. These samples of art make more ancient history of city culture of Azerbaijan and in whole play nard. There were found knife handles, rare geometrical decorations, samples of pipe and other instruments here.

During excavations there was found bone products that used as raw materials and cutting with pipe. In XI- XIII centuries this sphere of art was developing mostly. This thought is proved with a lot of bone and horn, found in zone of excavation. This period from bone there were prepared buttons, knifes and etc. Found during archeological excavations and used in wooden 
treatment and knife, showed that at the beginning of XI - XIII in and around Ganja this sphere of craftsmanship in exist.

In this ancient city printed cotton and calico fabrics have been widely produced. In traditional cloth productions the main place took the urban mines. In the early 30s of the XIX century in Ganja there were more than 164 people - weaving. The majority of these artists were weaving. In Ganja, which was the most important center of cloth production were produced different kinds of cotton cloth. Only in the 30s of the XIX century in Ganja were presently working 30 cloth bench. During one year this machine were producing 2000 of white cloth, 200 top of red cloth (shile) and nearly 400 benchchalamaya (thin cloth) spoke. In general, in Ganja from textile there were made cotton cloth with simple painting, various kinds' decorations. In most cases, in the XIX-XX centuries after coarse calico colored in white colors of, it colored to different colors [2-5; 7-9].

From the point of view silkworm breeding development and it's preparing technology there were two main forms of production: so-called raw silk weaving and felt weaving. In this important technological process it has such kind of production stages as cocoon opening, silk initial processing, preparing of raw silk, weaving technology, painting and decoration. In the ancient Ganja during the stage of the Middle Ages the great progress of silkworm was represented by raw silk weaving. For this reason, on the basis of local traditions production of delicate silk textiles from raw silk.

Historically the traditional art of saddle-making in Ganja developed in direction of cargo and passenger saddle making. The art of saddle-making within the local saddle-types and their components were determined on a specialization. The production of cargo or pack-saddle a rule was engaged by pack-saddle maker. For this reason, in most cases, the profession was called trade of pack-saddle maker.

Afterwards military, economic and transportation significance of hoarse was decrease, the demand for goods of saddle-making also was decrease. The reason of primitive saddlemaking decreasing was wide sale of cheaper factory products.

Samples of glass decorations, of BC, we met in the patterns of Ganjachay, Mingechevir, Xachbulaq and others. In these areas, the first centuries BC were found in samples of the glass plate. The majority of containers and the analysis based on graphical elements of the Roman scholars came to the opinion that the samples of the same scale as the Roman Empire through trade. There are more than 2000 beads in complex materials. Colored beads have prepared of different types products. Mostly distinguish beads that prepared from blue green and grey paste. A group of beads made of bone and antimony [3; 7-9]. A part of the hanging beads were prepared from cockleshells "Nassagibbosula" and "Suraeva Moneta". According to experts' thoughts, such kind of cockleshell that widely spared in the Indian and Pacific Ocean, also the Eastern Mediterranean region were put to Azerbaijan with economic relations. In III-V centuries, the local craftsmen themselves also became to produce better-designed containers. Among the local clay and glass utensils that found in and around Ganja there were big similarity in the form and also in the decoration. All the glass dishes found in and around Ganja are similar with the local clays on decoration of that period.

Glass dishes were containing of Iron, cobalt, magnesium and other elements, that were specific elements for Ganja and its surroundings. The development history of this sphere of craftsmanship can be determined only through archaeological research. In general, information about the development of this sphere of was found in 1959-1960 years, glass products in and around Ganja was obtained only at the end of the twentieth century. Results of archaeological excavations in the territory of Azerbaijan and research show that in the preparation of glass utensils were two technical methods: casting method and the method of blowing.

The first of these methods is more ancient, but in the Early Middle Ages and Middle Ages were used both of them. Produced glass alloys were transparent colored. By the addition of 
dusts of various metals in glass alloys people got colored glasses. We can see also to get her with different tinted green glasses also parts of blue, black and pink colored glass dish in sections of IX-X century in Shatal and Ganja. In IX-X centuries appeared dishes that had handle and spout. Among decorations of that period yellow, white and red beads of round and plain form are met mostly. At the beginning of X-XIII centuries development of production of glass in and around Ganja characterized by improvement from the technology point of view. Archaeological researches show, that outside of the cities in the VIII-IX centuries, also big settlements were established. This is often due to density in cities. The art of Textile materials, that concern to weaving craft, consists of spindle heads and needles. The remnants of dying from the Shamkir, Ganja,Shatal and Khunan proves development of dying here. Plant remains have been widely used in dying.

First of all, there have been discovered, that initial ceramic production in Ganja and its surrounding regions are belong to the VIII-VII millennium BC. From the history point of view, these ancient clay vessels, belonging to the Neolithic stage, are differing from the pottery samples of the neighboring ethnic in number characteristics. These differences are seen in preparing technology, also in the area of external surface decoration. From the construction point of view, samples of pottery, that concern to Antique period, also to the period of Hellenism in Ganja, differed in various forms as pictorial vases, ceramic figures and connected dishes. Pottery dishes, that concern to the first stages of Middle Ages of Ganja, are differing from the ceramic samples of Antique period in two features: on shape and for preparing techniques.

Along with the works and notes of medieval authors and travelers, a lot of material samples, found in the territory of ancient Ganja, also found in Mingachevir and concern to Middle Ages trough, ladle, wooden threshing board, shows that in Ganja wood treatment and sculptor art have a rich tradition. Wood treatment products historically have been represented in various fields of social and cultural life in Ganja. Abundance of local raw materials created favorable conditions for development of metal treatment from ancient times. In general, in the third millennium BC there was high culture of the Bronze Age in our country and in the first millennium transition period from Bronze Age to Iron Age began. In that period in Azerbaijan there were appeared several branches of metallurgy treatment. Jewelries, daggers, arms, copper products and other samples of art have been treated so refined, that in nowadays they are protected as very valuable exhibits in famous museums in such cities, as Paris, London, Brussels, Istanbul, Tehran and other cities.

Works of art, made from metal, for their content and their form are divided into two major groups: products of art and household goods. Household equipment, works of art, agriculture instruments have been executed into two main technical methods-casting and forging.

On the basis of innovative methods investigation of local craft and national cultural traditions of Ganja as the main features of urban culture is necessary. Scientific and archaeological researches have proved that Ganja was cradle of science and culture not only of Azerbaijan, but also of the whole East. Historically, Ganja city has been managed by government agencies, along with the elders. Folklore materials, collected from Ganja and historical information are confirming sayings. Ganja kitchen with its national characteristics is differs from other regions of Azerbaijan. The cooked dishes, prepared sweets, sherbet (sweet drink) are differing for their tasty and manufacturing technology. Ganja has a positive impact on national food composition in the human body, is the health service. In Ganja relationship ties are very strong. It is the tradition of Ganja people to often visit relatives, and to share their sadness and happiness. In whole Ganja's traditions are leading to spiritual pureness, they are collection of the universe laws to perfection, way of nation. Different facts are good example of that, the urban culture has been on a wide area of Ganjabasar more than 4000 years. In 
nowadays, when people speak about its historical, geographical location and position they mean the area of Ganjabasar. This area in various stages of the history was named as Ganja-Karabakh beylerbeylik, Elizavetpol province, also Ganjabasar with the center in Ganja. Nowadays, the historical territory of Ganja is also named Ganja-Kazakh economic region or Western region. This area includes Agstafa, Dashkasan, Gadabay, Goranboy, Goygol, Kazakh, Samukh, Tovuz administrative regions, cities Ganja and Naftalan. Ganjabasar is one of the richest areas from archaeological point of view. As a result of archaeological investigations here were found samples of material culture that concerned to the stages of different history period. Today most of them are kept in various museums of the world. The flint tools, that found in Gillikdag workshop and camp around Ganja, ladle, that were found by a prominent Azerbaijani archaeologist Isag Jafarzade, give the reason to say, that people, who lived in this area in VII - VI millennium BC were the founders of the Late Stone Age culture. Archaeological investigations prove that in this period the main population of this region had sedentary lifestyle and were engaged with farming. In V millennium BC in Ganja region all known to us domestic animals were domesticated. This fact is approved with osteology remainders that were found during archaeological excavations. The anonymous author of the article "Russian city" gave the schedule indicating the date of cities of the South Caucasus, also of Azerbaijan. And here he matched, that Ganja was founded in II century BC - IV century AD.

Protecting the status of capital city Ganja, in the various stages of the history, had an important role in the preservation of the ancient statehood traditions of Azerbaijan. At the end of the VII century Ganja was the provincial city of Arabs, in the X century the capital of Arran, in the XI century Seljuk's, in the XII-XIII centuries was the residences of Atabek's empire. During this period Ganja had renaissance time of its development, science, culture, trade, crafts reached the highest peak.

As a result of scientific researches by the well-known arabist and scientist on Nizami's work Bertels have been proved, that during the terrible earthquake in Ganja in 1139, 3 thousand people died. This fact is reflecting the city's power and greatness again. For comparison, it is also appropriate to note that, in the middle of the XIII century, in the great European city in Paris, lived nearly 100 thousand and in London nearly 40-50 thousand people [3; 4].

Ganja and its surrounded territory are also rich with different stones. Presentation of white and in mountain and Aran Karabakh and also lime, travertin and marble building stones in and around Ganja, pure white, a lot of colored aqats, chalsedons, viel, ametist, obsidian, aqats, crystal and other kind of rare colored stones in the river basins of Shahdag, Kecheldag, and other territories created favorable ground for developing in this ancient country from ancient times stone cutting, stone grind, stone polishing and for building great modern, columned, arched, circled and four-cornered buildings here. Among archaeological equipment there have been found two big boards from stone camel eyes [1-6].

These rare discover in and around Ganja are known from the archaeological investigations in ancient cultural, art and trade centers of Azerbaijan. The best samples of monuments, that concern to stone treatment are consists of column props, mill and gridding stones. In whole there were founded in and around Ganja a lot of samples, that concern to $\mathrm{X}$ century. They are consisting of stone figure, mills and column props.

Mill is usually prepared from volcanic, quartz, limestone and basalt. They used for grinding seed, millet, salt and for other aims [6-9]. We meet mostly mill stones, scales and pumice stone in stone treatment. At the same time there were used hewed stones for decorating buildings. In this period there were prepared decorations from precious stone. In traditional production of cloth manufactory trade historically played an important place. This kind of craft that developed on the basis of local raw materials was tied with cotton-growing economy. Since the time of the early Middle Ages, Ganja has been the main center of Azerbaijan in production 
of cotton cloth. In this ancient city printed cotton and calico fabrics have been widely produced. In traditional cloth productions the main place took the urban mines [4-7].

\section{Bibliography:}

1. Ohmədov F.M. Gəncə şəhərinin yerdəyişmələri / Gəncə tarixinin aktual problemləri. II elmi-praktik konfransın materialları. Gəncə: Elm, 2010, s. 53-63

2. Guliyeva N.M., Hasanov E.L. About ethnographic-archaeological research of some handicraft branches of Ganja during XIX - XX centuries / Progressive scientific explorations - 2012: Proceedings of the 8th International scientific-practical conference. Prague: Publishing House - Education and Science s.r.o., Prague, (Czech Republic), 2012, p. 73-75

3. Azərbaycan etnoqrafiyası: 3 cilddə, I c., Bakı: Şərq-Qərb, 2007, 544 s.

4. Həsənov E.L. Gəncə İmamzadə türbəsi (tarixi - etnoqrafik tədqiqat). Bakı: Elm və təhsil, 2012, $268 \mathrm{~s}$.

5. The dawn of Art. Leningrad: Aurora Art Publishers, 1974, 196 p.

6. Guliyeva N.M., Hasanov E.L. New ethnographic approach to the research of main decorative - applied arts of Ganja of the XIX - XX centuries / International scientific conference - Achievements in science: new views, problems, innovations. Lodz, (Poland) 2012, p. 56-58

7. Кавказский календарь на 1854 г. Тифлис, 1853, с. 338-341

8. Häsänov E.L. Die Gändschänischen teppiche von XIX - XX Jahrhundert als geschichtliche - ethnographische quelle / European Science and Technology (Die Europäische Wissenschaft und die Technologien): $2^{\text {nd }}$ International scientific conference. Bildungszentrum Rdk e. V. Wiesbaden, (Germany) 2012, p. 26-27

9. Ergenekon Cavidan. Tempe keçe sanatında geleneksel süsleme üsulları ve günümüzde bu saneye yönelik yeni yaklaşımlar / Azərbaycan xalçası və xalq tətbiqi sənəti mövzusunda III Beynəlxalq simpoziumun materialları. Bakı: Elm, 2005, s. 45-46 